\title{
Suomalainen pihatto lehmän näkökulmasta
}

\author{
Kristiina Hakkarainen ${ }^{1)}$, Tapani Kivinen ${ }^{2)}$, Kim O. Kaustell ${ }^{3)}$, Timo Hurme ${ }^{4)}$, Veli-Matti Tuure ${ }^{5)}$, Janne \\ Karttunen ${ }^{5)}$ \\ 1) Helsingin yliopisto, eläinlääketieteellinen tiedekunta, Kliinisen tuotantoeläinlääketieteen laitos, \\ Saaren yksikkö, Pohjoinen pikatie 800, 04920 Saarentaus, kristiina.hakkarainen@helsinki.fi, \\ ${ }^{2)}$ MTT, Kotieläintuotannon tutkimus, Vakolantie 55, 03400 Vihti, tapani.kivinen@mtt.fi \\ ${ }^{3)}$ MTT, Taloustutkimus, Vakolantie 55, 03400 Vihti, kim.kaustell@mtt.fi \\ ${ }^{4)}$ MTT, Palveluyksikkö, 31400 Jokioinen, timo.hurme@mtt.fi \\ ${ }^{5)}$ TTS tutkimus, luonnonvara-ala, PL 5, 05201 Rajamäki, veli-matti.tuure@tts.fi, jan- \\ ne.karttunen@tts.fi
}

\section{Tiivistelmä}

Kirjoituksessa esitellään vuosina 2004 - 2006 toteutetun kotimaisen pihattotutkimuksen, "Lypsykarjarakennusten toiminnalliset mitoitusvaihtoehdot", tuloksia. Pihattotutkimukseen osallistui 100, keskilehmäluvultaan yli 40 lehmän tilaa eri puolilta Suomea. Tutkimusten tulosten mukaan Suomalaisissa pihatoissa asuvilla lehmillä esiintyy runsaasti ihovaurioita. Lehmistä viidesosa ontui, ja suurimmalla osalla tiloista olisi selvästi parannettavaa lehmien jalkojen puhtaudessa. Kinnervaurioiden esiintyvyyteen olivat yhteydessä lehmän poikimakerta, makuuparren leveys ja käytetty kuivikemateriaali. Ontumisen esiintyvyyteen olivat yhteydessä lehmän rotu ja poikimakerta, lantakäytävän liukkaus, ruokintakäytävän leveys, ruokintaesteen malli ja veden tarjontatapa. Lehmien jalkojen puhtauteen olivat yhteydessä niskapuomin korkeus ja lantakäytävän pintamateriaali. Maidon solulukuun olivat yhteydessä kiimaisten erottaminen ryhmästä ja tunnutettavien hiehojen siirtoaika lehmien joukkoon. Koelypsypäivän maitotuotokseen olivat yhteydessä väkirehuautomaattien lukumäärä, ruokintakäytävän leveys, niskapuomin korkeus ja parren kaltevuus. Tulevaisuuden pihatoissa tulisi lantakäytävien olla nykyistä leveämpiä, parsien suurempia ja pehmeämpiä, ja ruokintapöytätilaa olla enemmän lehmää kohden. Lannanpoiston toimivuuteen tulisi kiinnittää nykyistä enemmän huomiota. Tutkimuksen loppuraportti ja pihaton uudet mitoitussuositukset löytyvät internetosoitteesta http://www.mtt.fi/mtts/pdf/mtts137.pdf

Avainsanat: pihatto, lypsylehmä, terveys, hyvinvointi, ontuminen, ihovauriot, maidontuotos, soluluku, puhtaus, mitoitus

\section{Johdanto}

Vuosina 2004-2006 toteutimme Suomessa laajan pihattotutkimuksen, jonka lopputuloksena saatiin aikaan ensimmäiset kotimaiset makuuparsipihatoiden mitoitussuositukset. Tutkimus koostui kirjallisuuskatsauksesta, sadan tilan tilatutkimuksesta ja hyvien malliratkaisujen suunnittelusta. Tutkimuksessa tarkasteltiin pihattojen toimivuutta sekä karjan hoitajan että pihatossa asuvien nautojen näkökulmasta. Tutkimuksen toteuttajatahoina toimivat Maa- ja elintarviketalouden tutkimuskeskus, TTS-tutkimus, ja Helsingin yliopiston eläinlääketieteellinen tiedekunta. Yhteistyötä tehtiin Valio Oy:n ja Savonia-amk:n hallinnoiman ELKE-hankkeen kanssa.

\section{Aineisto ja menetelmät}

Otanta suoritettiin niin, että kaikille karjantarkkailussa mukana oleville, keskilehmäluvultaan yli 40 lehmän tiloille $(\mathrm{n}=785)$ lähetettiin kirje, jossa kysyttiin halukkuutta osallistua tutkimukseen. Vapaaehtoisista $(\mathrm{n}=158)$ mukaan valittiin kaikki tilat $(\mathrm{n}=103,65 \%)$ joilla oli lämpöeristetty pihatto, joka oli otettu käyttöön vuosien 1990-2002 aikana. Kolme tilaa poistui kesken tutkimuksen, ja lopullisina tutkimustiloina oli 100 makuuparsipihattoa, jotka oli otettu käyttöön vuosina 1998-2002. Lehmien terveyttä ja hyvinvointia tarkasteltiin karjantarkkailutietojen, tilakäyntien aikana tehtyjen havaintojen ja kyselykaavakkeiden avulla. Tuotanto-olosuhteita, hoitokäytäntöjä, sairauksien hoitoja ja poistonsyitä analysoitiin kuvailevasti. Lehmien hyvinvoinnin tärkeimpiin osa-alueisiin vaikuttavia tekijöitä tarkasteltiin lisäksi monimuuttujamallien 
avulla, jolloin mittareiksi valittiin 1) ihovauriot kintereissä, 2) maidon soluluku, 3) ontuminen ja 4) maitotuotos. Mittarien valinnassa painotettiin käytännön näkökulmaa; valituilla mittareilla on vahva yhteys sekä lehmän hyvinvointiin että tuotannon taloudelliseen kannattavuuteen. Ihovaurioiden esiintyminen on yhteydessä levon laatuun, maidon solujen utareterveyteen, ontumisen jalkaterveyteen, ja tuotoksen rehun ja veden saantiin. Tilastollista mallinnusta varten lehmäkohtaisesti mitatuista arvoista estimoitiin tilalle lehmän rodulla ja poikimakerralla vakioitu keskiarvo jota vasten tutkittavat muuttujat testattiin. Ensin haettiin vastemuuttujaan vaikuttavat yleisluontoiset sekoittavat tekijät ( $\mathrm{mm}$. mittauksen tekijä). Seuraavaksi testattiin muut sekoittavat tekijät, erikseen kullekin selitysmallille. Tämän jälkeen testattiin varsinaisia selittäviä tekijöitä. Mallinnuksessa huomioitiin tilastollisen mallin oletukset kaikissa vaiheissa. Jäännösten normaalijakaumaoletusta tutkittiin, ja tarvittaessa käytettiin muunnoksia. Yksittäisten selittävien muuttujien arvoja tutkittiin myös puuttuvien havaintojen sekä mahdollisten poikkeamien varalta. Lopullisesta mallista tutkittiin myös jäännösten jakaumaa. Lopullisissa malleissa käytettiin: 1) arkussinimuunnosta tutkittaessa kinnervaurioita, 2) logaritmimuunnosta maidon soluluvulla, sekä 3) neliöjuurimuunnosta ontumisella. Lopputulosten keskiarvoestimaatit ja niiden luottamusvälit palautettiin takaisin alkuperäiselle asteikolle. Tilastolliset mallinnukset toteutettiin pääosin SAS-ohjelmiston MIXED-proseduurilla (SAS Institute Inc., Cary, NC, USA). Joitain mallinnuksia tehtiin STATA ${ }^{\circledR}$-ohjelmalla (StataCorp, 2006).

\section{Tulokset}

Tutkimustilojen navetta oli otettu useimmiten käyttöön vuosien 1999 - 2002 aikana (85 \%), mutta mukana oli vanhempiakin navetoita, käyttöönottovuosiltaan 1997- 1998 (13 \%) ja 1994 - 1995 (2 \%). Vuonna 2004 tutkimukseen osallistuneiden tilojen keskilehmäluvun mediaani oli 52,7 (39,5 - 104,8). Kaikilla tiloilla oli eristetty makuuparsipihatto, yleisimmin 3-rivinen (72\%), 4-rivinen (17\%) tai 2-rivinen (7\%). Lypsyasemana oli useimmiten kalanruotoasema (42\%), tandemasema (38\%), tai lypsyrobotti (8\%). Lattiaratkaisuna oli lähes yhtä usein ritiläpohja (52\%) kuin avokourukin (48 \%). Lantakäytävän pintamateriaali oli melkein kaikilla tiloilla (98 \%) betoni, yhdellä tilalla oli käytävällä kumimatto ja yhden käytävä oli asfalttia. Lantakäytävä arvioitiin yhtä usein joko pitäväksi $(48 \%, n=43)$ tai lievästi liukkaaksi (48 \%, n=43), erittäin liukas käytävä oli neljällä tilalla. Käytävämallien välillä ei ollut juurikaan eroa pinnan pitävyydessä. Käytävien leveydet olivat keskimäärin selvästi nykyisiä suosituksia kapeammat. Ruokintakäytävän leveys oli keskimäärin $324 \mathrm{~cm}(\mathrm{sd}=34)$, vaihdellen $200 \mathrm{~cm}$ :stä $535 \mathrm{~cm}$ :iin. Parsirivien välinen käytävä oli keskimäärin $235 \mathrm{~cm}(\mathrm{sd}=23,180$ - $322 \mathrm{~cm})$. Ruokintapöytätilaa oli lypsävien osastossa keskimäärin (mediaani) $50 \mathrm{~cm}$ parsipaikkaa kohden (29-127 cm). Ruokintaesteeksi oli yhtä usein valittu pelkkä niskapuomi $(n=49)$ tai ruokintapaikkoihin jaettu malli $(n=49)$. Väkirehuautomaatteja oli lypsävien ryhmässä lehmää kohden (per keskilehmäluku) 2,2 prosentista 8,6 prosenttiin, keskiarvon ollessa 5,2 \%. Väkirehuautomaatissa oli takaportti 14 tilalla, 65 tilalla takaporttia ei ollut. Kaikilla tiloilla, joilla ei ollut takaporttia, esiintyi häirintää automaateilla.

Ylitäyttö oli suhteellisen yleistä lypsävien osastossa. Kolmasosalla $(32 \%, \mathrm{n}=31)$ tiloista lehmiä oli parsipaikkoja enemmän, 68 \%:1la ( $\mathrm{n}=67)$ parsia oli vähintään yksi lehmää kohden. Parsien mitoitus, ominaisuudet ja säädöt vaihtelivat huomattavasti tilojen välillä. Parret olivat yleisesti nykyisiä suosituksia lyhyempiä. Päät vastakkain olevien parsien pituus oli keskimäärin $232 \mathrm{~cm}(\mathrm{sd}=12,76)$ vaihdellen $200 \mathrm{ja} 275$ $\mathrm{cm}: n$ välillä. Muiden (pääosin seinää vasten olevien) parsien pituus oli keskimäärin $242 \mathrm{~cm}(\mathrm{sd}=20,32$; $200-345 \mathrm{~cm})$. Parsien leveys (erottajan keskeltä keskelle) oli yleisimmin $120 \mathrm{~cm}(\mathrm{n}=65)$. Parret olivat edellistä kapeampia kuudella, ja leveämpiä 28 tilalla. Suurimmalla osalla tiloista niskapuomi oli turhan matalalla tai takana, ja lehmien pään edessä oli ylös nousemista haittaavia rakenteita. Parressa käytettiin useimmiten $(87 \%, n=74)$ parsimattoa tai -petiä. Mattojen ja petien ominaisuuksia arvioitiin 61 tilalla. $82 \%: 1 l a$ käytössä oli kumimatto, $13 \%$ :lla kumirouheesta tehty parsipeti, ja kolmella kumimatto jonka alla oli pehmuste. Kumimatot havaittiin yleensä koviksi $(89 \%, n=43)$. Kumirouhematot ja matot, joissa oli kumimaton alla pehmuste, arvioitiin poikkeuksetta $(100 \%, \mathrm{n}=11)$ pehmeiksi. Parsissa käytettiin kuivikeena kutteria $(35 \%, \mathrm{n}=29)$, turvetta $(33 \%, \mathrm{n}=28)$, turpeen ja muun kuivikkeen seosta $(13 \%, \mathrm{n}=11)$, sahanpurua $(10 \%, n=8)$, olkea $(6 \%, n=5)$, sekä sahanpurun ja kutterin seosta $(4 \%, n=3)$. Kumimattojen kanssa käytettiin yleisimmin kutteria, rouhepetien kanssa turvetta tai turveseosta. Kuiviketta oli makuuparsissa useimmilla tiloilla alle $3 \mathrm{~cm}: n$ kerros $(75 \%, \mathrm{n}=74)$ tai ei lainkaan $(15 \%, \mathrm{n}=15)$. Yli $3 \mathrm{~cm}: \mathrm{n}$ kuivikekerros havaittiin 10 tilalla (10\%). Parsien kaltevuus oli yleisimmin $2 \frac{1}{2}-3 \%(31 \%, n=27) ; 3 \frac{1}{2}-4 \%(25 \%, n=22)$, 
$2 \%(17 \%, n=15)$ tai $5 \%(15 \%, n=13)$.

\section{Terveys, tuotos, hoidot ja poistot}

Tutkimuskarjojen keskituotosten keskiarvo oli $8964 \mathrm{~kg}(\mathrm{sd}=827,5)$. Ensikoiden keskituotosten keskiarvo oli $7639 \mathrm{~kg}(\mathrm{sd}=901,3)$ ja vanhempien lehmien $10053 \mathrm{~kg}(\mathrm{sd}=1151,5)$. Keskipoikimakerta vaihteli 1,7:stä 3,3 :een, ollen keskimäärin 2,3. Poikimavälin keskiarvo oli 389 pv (sd=16,8), ja siemennyksiä käytettiin keskimäärin 1,79 poikimista kohden. Joidenkin yleisesti hoidettujen sairauksien hoitoinsidenssien mediaanit olivat: akuutti utaretulehdus 17,7 \% (13,9-62,1\%), piilevä utaretulehdus $0,5 \%(0-23,5 \%)$, hiljainen kiima 2,4 \% (0 - 19,3\%), rakkulat 2,4 \% (0-19,3\%), poikimahalvaus 5,3\% (0-18,5\%), asetonitauti $0 \%(0-10,0 \%)$, juoksutusmahan laajentuma ja siirtymä $0 \%(0-3,8 \%)$. Karjojen poistoprosenttien keskiarvo oli $34(\mathrm{sd}=11,45)$, vaihdellen 14 ja $83 \%$ :n välillä. Lehmät poistettiin keskimäärin 4,6 vuoden iässä $(\mathrm{sd}=0,64)$. Yleisimmät poiston syyt olivat utaretulehdus ( $25 \%$ poistetuista), hedelmällisyyshäiriö (18 $\%)$, huono tuotos (12\%), utarerakenne (12\%), vedinvika (8\%) ja jalkavika (6\%).

\section{Ihovaurioiden esiintyvyys}

Ihovaurioiden esiintyvyyttä arvioitiin 98 tilalla yhteensä 1465 lehmältä (15/tila). Kinnervauriot olivat tutkituissa pihatoissa yleisiä. Kinnervaurioita esiintyi $95 \%$ :lla tiloista ja $64 \%$ :1la tarkastelluista lehmistä. Lehmistä 53 \%:lla vaurio oli lievä (karvaton alue), ja $11 \%$ :lla vakava (iho rikki). Vanhemmilla lehmillä ihovaurioita esiintyi enemmän kuin ensikoilla (OR 1,3; P=0,014; $\mathrm{CI}=1,06-1,60)$. Kinnervaurioiden arviointituloksista muodostettiin lehmien rodulla ja poikimakerralla korjattu tilakohtainen keskiarvoestimaatti. Vaurioiden esiintyvyyden yhteyttä navettaolosuhteisiin tarkasteltiin monimuuttujamallin avulla, jossa huomioitiin sekoittavana tekijänä arvioinnin suorittaja. Kinnervaurioiden esiintymisen todennäköisyyteen olivat tilastollisesti merkitsevästi yhteydessä parren leveys $(\mathrm{P}=0,074)$ ja kuivikemateriaali $(\mathrm{P}=0,001)$. Vaurion todennäköisyys oli pienin kun parren leveys oli $126-130 \mathrm{~cm}$ (estimaatti $41 \%$ ), edellistä kapeampiin parsiin verrattuna ( $54 \%$ kun leveys $121-125 \mathrm{~cm}, 62 \%$ kun $\leq 120 \mathrm{~cm}$ ). Turve (estimaatti $42 \%$ ) tai turpeen ja muun kuivikkeen seos (38\%) olivat kuivikemateriaaleina parempia kuin olki (69\%) tai sahanpuru, kutteri tai edellisten seos $(61 \%)$.

\section{Utareterveys}

Kunkin tilan kaikkien lehmien kaikista koelypsyistä (vuosi 2004) muodostettiin lehmien rodulla ja poikimakerralla painotettu keskiarvoestimaatti. Navettaolosuhteiden ja hoitokäytäntöjen ja soluluvun välistä yhteyttä tarkasteltiin monimuuttujamallin avulla, jossa sekoittavina tekijöinä huomioitiin karjan keskituotos, poistoprosentti ja keskilehmäluku. Solulukuun olivat yhteydessä kiimaisten lehmien erottaminen $(\mathrm{P}=0,039)$ ja tunnutettavien hiehojen siirtoaika $(\mathrm{P}=0,123)$. Tiloilla joilla lehmistä yli $50 \%$ osoitti kiimaa hyppimällä, soluluvun estimaatti oli suurin $(241000 \mathrm{kpl} / 100 \mathrm{ml})$ jos kiimaisia lehmiä ei otettu ryhmästä eroon koskaan, pienempi (191 $000 \mathrm{kpl} / 100 \mathrm{ml})$ jos kiimaiset otettiin eroon joskus, ja alhaisin (177 136 $\mathrm{kpl} / 100 \mathrm{ml}$ ) kun kiimaiset erotettiin aina. Soluluku oli sitä pienempi mitä aikaisemmin ensikot siirrettiin lehmien joukkoon (estimaatti 199>196>193>189 > $183 \times 10^{3} \mathrm{kpl} / 100 \mathrm{ml}$, kun siirtoaika $7>14>21>$ $30>45$ pv ennen poikimista).

\section{Jalkaterveys}

Lehmien jalkaterveyttä arvioitiin tarkastelemalla ontuvien lehmien määrää tutkimustiloilla. Kaikkiaan arvioitiin 4145 lehmän käyntiä 92 karjassa. Arvioiduista lehmistä $22 \%$ ontui. Ontumisen prevalenssi vaihteli huomattavasti tilojen välillä $(2-53 \%)$, keskiarvon ollessa $19 \%$. Holsteinit ontuivat Ayrshirejä todennäköisemmin (OR 1,6; P <0,001; CI=1,2 - 1,9). Ontumisen todennäköisyys kasvoi poikimakertojen myötä; ensikoita todennäköisemmin ontuivat sekä toisen kerran poikineet (OR 1,4; $\mathrm{P}=0,086$; CI 0,9 - 2,1), että vähintään kolmesti poikineet lehmät (OR 3,9; $\mathrm{P}<0,001$; CI 2,6 - 5,7). Ontumistuloksista muodostettiin karjakohtainen, lehmien rodulla ja poikimakerralla korjattu keskiarvoestimaatti. Ontumisen ja navettaolosuhteiden välisiä yhteyksiä tarkasteltiin monimuuttujamallin avulla, jossa huomioitiin sekoittavina tekijöinä arvioija, arviointialusta ja päivittäisten lannanpoistokertojen lukumäärä. Ontumisen esiintyvyyteen olivat yhteydessä lantakäytävän liukkaus $(\mathrm{P}=0,021)$, ruokintakäytävän leveys $(\mathrm{P}=0,060)$, ruokintaesteen malli $(\mathrm{P}=0,010)$ ja veden tarjontatapa $(\mathrm{P}=0,018)$. Ontumisen esiintyvyyden todennäköisyys oli suurempi tiloilla joilla lantakäytävä oli erittäin liukas (estimaatti $28 \%$ ), kuin tiloilla joilla käytävä oli lievästi liukas $(16 \%)$ tai pitävä (15\%). Ontumisen todennäköisyys oli pienempi jos ruokintakäytävä oli leveämpi (16\% kun käytävä yli 340 cm, $21 \%$ kun $320-340 \mathrm{~cm}, 22 \%$ kun alle $320 \mathrm{~cm}$ ). Ruokintapaikkoihin jaettu ruo- 
kintaeste oli ontumisen näkökulmasta parempi kuin pelkkä niskapuomi (estimaatti $17 \%$ vs. $22 \%$ ). Ontumisen todennäköisyys oli pienempi jos juomavesi tarjottiin sekä altaista että vesikupeista (estimaatti 17 \%), kun jos käytössä olivat pelkät altaat (22\%). Ontumisen esiintyvyyden ja koelypsypäivän maitotuotoksen välillä havaittiin yhteys. Yhden prosenttiyksikön lisäys karjan ontumisestimaatissa vastasi keskimäärin 3,6 kg:n vähenemistä koelypsypäivän maitomäärässä lehmää kohden.

\section{Tuotos}

Tuotoksen ja navettaolosuhteiden yhteyttä tarkasteltiin vuoden 2004 koelypsyjen maitomäärien avulla. Koelypsyjen tuotoksista muodostettiin karjakohtainen, lehmien rodulla ja poikimakerralla korjattu keskiarvoestimaatti. Tuotoksen ja navettaolosuhteiden välisiä yhteyksiä tarkasteltiin monimuuttujamallin avulla. Koelypsypäivän maitomäärä oli yhteydessä väkirehuautomaattien lukumäärään $(\mathrm{P}=0,046)$, parren kaltevuuteen $(\mathrm{P}=0,020)$, niskapuomin korkeuteen $(\mathrm{P}=0,097)$ ja ruokintakäytävän leveyteen $(\mathrm{P}=0,139)$. Lehmät tuottivat $1,0 \mathrm{~kg}$ enemmän $(23,1$ vs. 22,1$)$ maitoa päivässä kun väkirehuautomaatteja oli enemmän kuin $0,05 \mathrm{x}$ keskilehmäluku. Tuotos oli sitä korkeampi, mitä korkeammalla niskapuomi oli parressa. Ero tuotoksessa oli jopa $3,7 \mathrm{~kg}$ per lehmä päivässä $(23,7$ vs. 21,0$)$ kun verrattiin tiloja joilla puomi oli korkeimmalla $(116-120 \mathrm{~cm})$ tai matalimmalla $(88-99 \mathrm{~cm})$. Ero ryhmään joilla puomi oli $110-115 \mathrm{~cm}$ korkeudessa oli $1,0 \mathrm{~kg}$ per lehmä päivässä. Tuotos oli noin $1 \mathrm{~kg}$ (per lehmä per pv) parempi tiloilla joilla ruokintakäytävä oli vähintään $320 \mathrm{~cm}$, verrattuna tiloihin joilla käytävä oli edellistä kapeampi. Tuotos oli noin kilon parempi (per lehmä per pv) kun parren kallistus oli korkeintaan $3 \%$.

\section{Lehmien puhtaus}

Lehmien puhtautta arvioitiin 98 tilalla, yhteensä 1465 lehmää (15/tila). Puhtaus arvioitiin kolmiportaisella asteikolla $(0=$ puhdas, $1=$ alle $50 \%$ alueesta likaantunut, $2=y l i ~ 50 \%$ alueesta likaantunut $)$, ja karjassa arvioitujen lehmien tuloksista laskettiin tilakohtainen keskiarvo. Lehmien utareen puhtaus oli suurimmalla osalla tiloista (68 \%) hyvä, viidesosalla kohtalainen, ja $12 \%: 1 l a$ huono. Lehmien jalkojen puhtaus sitä vastoin oli hyvä vain $32 \%$ :lla tiloista, kohtalainen $43 \%$ :lla ja huono $25 \%$ :lla tiloista. Lehmien jalkojen puhtauden ja navettaolosuhteiden välisiä yhteyksiä tarkasteltiin monimuuttujamallin avulla. Lehmien jalat olivat puhtaammat silloin kun niskapuomi oli parsissa korkeammalla $(0,12$ yksikköä / $10 \mathrm{~cm}, \mathrm{P}=0,026$, $\mathrm{CI}=0,01-0,22)$, ja kun lantakäytävän pintana oli ritiläpalkkilattia $(0,4$ yksikköä; $\mathrm{P}<0,001 ; \mathrm{CI}=0,24-$ $0,49)$ verrattuna avokouruun.

\section{Pohdinta ja johtopäätökset}

\section{Parren olosuhteet}

Tutkimuksen tulosten ja aiemman kirjallisuuden perusteella voidaan tehdä seuraavat johtopäätökset:

- Parsien tulisi olla keskimäärin nykyistä pehmeämpiä. Parsipeti on suositeltavin pintavaihtoehto.

- Parsien tulee olla riittävän pitkiä - sijoituspaikasta ja lehmien koosta riippuen $245-300 \mathrm{~cm}$.

- Suositeltava parren leveys on $130 \pm 10 \mathrm{~cm}$.

- Parren kaltevuus kannattaa tehdä maltilliseksi, parren pintamateriaali voi vaikuttaa kaltevuuteen.

- Turve tai turpeen ja purun/kutterin seos on suositeltavin kuivikemateriaali. Kuiviketta tulisi useimmilla tiloilla käyttää nykyistä runsaammin. Parsia tulee puhdistaa ja kuivittaa riittävän usein.

- Parsi tulee säätää lehmille riittävän väljäksi. Lehmän pään edessä ei saa olla haittaavia rakenteita.

Tutkimuksessamme havaittiin että kinnervauriot olivat erittäin yleisiä. Useimmilla tiloilla käytettiin parsimattoja, jotka ovat liian kovia lehmän makuualustana. Kinnervaurioiden esiintymisen todennäköisyys oli pienempi silloin kun parsi oli leveämpi. Turve ja turpeen seos olivat kuivikemateriaaleina parempia kuin olki, sahanpuru, kutteri tai edellisten seos. Kumimattojen kanssa käytettiin yleisimmin kutteria, ja parsipetien (kumirouhe) kanssa turvetta ja turpeen ja muun kuivikkeen seosta. Kuivikkeiden käyttö oli niukahkoa. Turvetta käytettiin eniten pehmeiden petien kanssa, mikä saattaa osaltaan selittää tulosta. Turve on kuitenkin materiaaleista pehmein, ja pysynee esimerkiksi olkea paremmin paikoillaan, vähentäen ihon hankautumista parren pintaa vasten. Vanhemmilla (yleensä isompia ja painavampia) lehmillä esiintyi enemmän kinnervaurioita, niskavaurioita ja ontumista. Tämä viittaa siihen, että parsi oli useilla tiloilla isoille lehmille liian ahdas ja kova. Useimmilla tiloilla ei osattu säätää partta oikein ja lehmän pään edessä oli liikkeitä 
häiritseviä putkia. Tuotos oli sitä korkeampi, mitä korkeammalla niskapuomi sijaitsi, ja lehmien jalat olivat puhtaammat niillä tiloilla joilla niskapuomi oli korkeammalla.

Aiemmissa tutkimuksissa on todettu että mitä pehmeämpi alusta on, sitä parempi se on lehmälle. Lehmille parren pintamateriaali vaikuttaisi merkitsevän jopa enemmän kuin parren mitoitus, ja ne valitsevat mieluiten pehmeän kuivituksen ja pintamateriaalin (Tucker ym., 2003). Hyvin kuivitetuissa parsissa lehmät makaavat ja märehtivät kauemmin ja niillä esiintyy vähemmän ihohankaumia ja ontumista (Tucker ja Weary, 2004; Oconnell ym., 1993; Weary ja Taszkun, 2000). Huonosti suunnitelluissa parsissa ja kovalla alustalla lehmillä on enemmän ylösnousu- ja makuullemenoyrityksiä, ne nousevat makuulta väärin, niillä on ihovaurioita ja vedinpolkemia, ja niiden sorkat altistuvat verenpurkaumille (Fregonesi ja Leaver, 2001; Webster, 2001; Lidfors, 1989; Radostits, 2001; Tucker ja Weary, 2004). Väärinsijoitettu niskapuomi aiheuttaa käyttäytymisongelmia ja loukkaantumisia. Pään tilan puuttuminen aiheuttaa eniten ongelmia makuullemenossa ja ylösnousussa (Veissier ym., 2004). Leveämmissä ja pidemmissä parsissa lehmät makaavat enemmän ja niillä esiintyy vähemmän puolittain parsissa seisomista (Oconnell ym., 1993; Galindo ja Broom, 2000), ja niillä on vähemmän ihovaurioita (Tucker ja Weary, 2004). Parrenerottajien huono suunnittelu, terävät kulmat parsissa sekä väärä mitoitus altistavat niveltulehduksille ja nivelpussintulehduksille (Livesey ym., 2002; Veissier ym., 2004). Lehmät suosivat parsipetejä enemmän kuin betonialustaa tai pelkkiä mattoja (Veissier ym., 2004). Parsipedeillä lehmät seisovat harvemmin joutilaana kuin parsimatoilla (Chaplin ym., 2000) ja niillä esiintyy vähemmän kinnerhankaumia (Tucker ym., 2003; Livesey ym., 2002).

\section{Lantakäytävät ja lannanpoisto}

Tutkimuksen tulosten ja aiemman kirjallisuuden perusteella voidaan tehdä seuraavat johtopäätökset:

- Lattioiden pintamateriaaleihin ja valun sekä pintojen viettoon on kiinnitettävä erityistä huomiota.

- Avokouru suositellaan pinnoitettavaksi kumimatolla.

- Ruokintakäytävän suositeltava leveys, rivisyydestä riippuen, on 3,40 metristä yli neljään metriin.

- Poikkikäytävät vaikuttavat lehmäliikenteen sujuvuuteen. Niiden tulee olla tarpeeksi leveitä ja niitä tulee olla riittävästi. Poikkikäytävien puhdistettavuuteen tulisi kiinnittää enemmän huomiota.

- Ritiläpalkkien päälle kannattaa asentaa lantaraappa. Avokourujen valun onnistuminen on haasteellista ongelmat näkyvät muun muassa nesteiden lammikoitumisena.

Tässä tutkimuksessa havaittiin että kulkukäytävät eivät olleet optimaalisia - ontuvia eläimiä oli turhan paljon. Useilla tiloilla on lannanpoistossa ongelmia, ja selvästi parantamisen varaa lehmien jalkojen puhtaudessa. Lehmien jalat olivat puhtaampia niillä tiloilla, joilla oli ritiläpalkkikäytävä. Ontumista esiintyi enemmän tiloilla, joilla käytävä oli liukas. Ontumisen todennäköisyys oli pienempi, ja tuotos parempi kun ruokintakäytävä oli leveämpi. Poikkikäytävien yhteenlaskettu pinta-ala oli kinnervauriomallissa sekoittava tekijä, mahdollisesti vaikuttaen todennäköisesti kulkemisen vaivattomuuteen.

Aiemmissa tutkimuksissa on todettu että toimimaton lannanpoisto, huono sorkkahygienia ja oleskelu lantaisilla, kovilla ja/tai liukkailla kulkuväylillä altistavat sorkkasairauksille (Rowlands ym., 1983; Bewley ym., 2001; Cook, 2003). Tehokas lannanpoisto pitää lattiapinnat kuivina ja puhtaina, ja myös lattioiden liukkaus vähenee (Stefanowska ym., 2001). Käytävämateriaali vaikuttaa lehmän askellukseen. Betonisella rakolattialla lehmillä oli lyhin askelpituus ja varovaisin kävely (Telezhenko ja Bergsten, 2005). Lehmät kokevat kumipäällysteisen kulkukäytävän miellyttävämmäksi kuin ilman päällystettä olevan (Fregonesi ym., 2004; Vokey ym., 2001; Telezhenko ja Bergsten, 2005). Kumimatolla lehmät kävelevät nopeammin ja niillä on pitempi ja korkeampi askel (Flower ym., 2007; Telezhenko ja Bergsten, 2005). Kumimattopäällysteellä on todettu positiivisia vaikutuksia myös lehmien jalkaterveyteen; lehmät ontuivat vähemmän, niiden sorkat kasvoivat ja kuluivat vähemmän, ja niille kehittyi vähemmän sorkan kannan syöpymiä (Vanegas ym. 2006).

Naudat toimivat mielellään samanaikaisesti. On erittäin tärkeää, että tilaa on niin paljon, että tämän käyttäytymistaipumuksen toteuttaminen on mahdollista (Cook ja Nordlund, 2004). Lattiatilan suurentamisen on havaittu kasvattavan lehmien välistä etäisyyttä (Kondo ym., 1989) ja vähentävän kilpailua, liikkumista ja toisen eläimen pois ajamista sekä loukkaantumisia (Menke ym., 1999; Boe ja Faerevik, 2003). Tilan 
vähentämisen on todettu lisäävän agonista, hierarkian ylläpitämiseen liittyvää, käytöstä (Fregonesi ja Leaver, 2002) ja aggressiivista käyttäytymistä (Kondo ym., 1989). Agonistisesta käyttäytymisestä suurin osa tapahtuu ruokintakäytävällä ja noin neljännes muilla kulkukäytävillä. Erityisesti arvoasteikossa alhaisessa asemassa olevien lehmien vapaa kulku estyy muiden lehmien toimesta (Miller ja Woodgush, 1991) ja pihaton väljyyden voidaan olettaa helpottavan erityisesti niiden elämää (Manson ja Appleby, 1990).

\section{Ryhmittelyt, sairaat ja poikivat}

Tutkimuksen tulosten ja aiemman kirjallisuuden perusteella voidaan tehdä seuraavat johtopäätökset:

- Tunnutettavat hiehot kannattaa siirtää lypsävien ryhmään noin 1-2 kk ennen poikimista. Tämä tulisi huomioida lypsävien osaston mitoituksessa.

- Kiimaiset eläimet kannattaa ottaa eroon muusta joukosta.

Tutkimuksessamme havaittiin että hiehojen siirtoaika lehmien joukkoon oli yhteydessä karjan solulukuun niin, että soluluku oli sitä alhaisempi, mitä aikaisemmin hiehot siirrettiin. Maidon soluluku oli alhaisempi tiloilla, joilla kiimaiset lehmät otettiin eroon muusta ryhmästä.

Aiemmissa tutkimuksissa on todettu että uuteen laumaan siirto aiheuttaa hiehoille stressiä (Boe ja Faerevik, 2003; Cook ja Nordlund, 2004). Niille tulee antaa riittävästi aikaa sopeutua uuteen ympäristöön ja opetella makuuparsien ja väkirehuautomaatin käyttöä (Kjaestad ja Myren, 2001). Hiehojen tarvitsee myös oppia kulkemaan lypsyasemalle tai robotille jo hyvissä ajoin ennen poikimista. Tanskalaisten suositusten mukaan ensikoiden suositeltava siirtoaika on 3 - 9 viikkoa ennen poikimista (Anon., 2002), riippuen siitä millaisessa ympäristössä ne ovat kasvaneet. Lehmien joukossa hiehojen on todettu liikkuvan enemmän, makailevan useammin lantakäytävillä ja käyvän useammin syömässä öisin (Boe ja Faerevik, 2003). Niillä esiintyy lehmien joukossa myös enemmän kaatumisia ja muita tapaturmia (Radostits, 2001). Hiehojen sorkat ovat lehmien sorkkia herkempiä vaurioitumaan, jolloin turha seisoskelu kostautuu helposti myös sorkkasairauksien muodossa. Lehmien joukossa hiehot joutuvat väistelemään ylempiarvoisia eläimiä ja ne seisoskelevat myös enemmän vain etujalat makuuparressa (Radostits, 2001; Phillips, 2002).

\section{Ruokinta- ja rehumenetelmät, veden saanti}

Tutkimuksen tulosten ja aiemman kirjallisuuden perusteella voidaan tehdä seuraavat johtopäätökset:

- Ruokintapöytätilaa tulee olla riittävästi.

- Ruokintaesteenä suositeltava vaihtoehto on sellainen, joka on jaettu ruokintapaikkoihin.

- Vesipisteitä tulee olla riittävästi ja ne tulee sijoittaa niin että ympärillä on riittävästi tilaa ja eikä valuva vesi seiso käytävällä.

- Väkirehuautomaatteja tulee olla noin yksi 15 lehmää kohden, jos kaikki väkirehu syötetään automaatin kautta.

Tutkimuksessamme havaittiin että ontumisen esiintyvyys oli vähäisempää tiloilla, joilla ruokintaesteenä oli paikkoihin jaettu malli, verrattuna niihin, joilla oli pelkkä niskapuomi. Juoma-altaiden sijoittelussa on ongelmia - ontumisen todennäköisyys oli pienempi tiloilla, joilla juomavesi tarjottiin pelkästään vesikupeista, verrattuna niihin, joilla oli käytössä sekä kupit että altaat. Väkirehukioskien lukumäärällä oli yhteys maitotuotokseen. Tuotos oli parempi niillä tiloilla joilla automaatteja oli enemmän.

Aiemmissa tutkimuksissa on todettu että ruokintapöytätilan kasvattaminen lisää lehmien syöntiaikaa ja vähentää toisen lehmän pois ajamisten määrää ja aggressiivisia yhteenottoja (Olofsson, 1999; Huzzey, ym., 2006; DeVries, ym., 2006). Arvoasteikossa matalalla olevat lehmät tulevat muita useammin ajetuksi pois kesken syömisen ja poisajamisten lukumäärä päivässä moninkertaistuu kun syöntipaikkojen lukumäärä lehmää kohden vähenee. Kun kilpailua on enemmän, syöntikerrat ja yöllä syöminen lisääntyvät, ja seisomisen suhteellinen osuus lisääntyy (Olofsson, 1999a). Syöttöparsia käytettäessä lehmien päivittäinen syöntiaika lisääntyi ja aggressiivisten yhteenottojen ja poisajamisten määrä väheni, pelkkään niskapuomiin verrattuna (DeVries, ym. 2006). Lukittuvassa ruokintaesteessä lehmillä esiintyi vähemmän paikanvaihtoja ja toisen pois ajamista kuin jos esteenä oli pelkkä niskapuomi (Huzzey, ym. 2006). Erityisesti arvoasteikossa alhaisempien lehmien on havaittu saavan syödä kauemmin, kun pöytä on jaettu ruokintapaikkoi- 
hin (Albright, 1993; Olofsson, 1999). Lehmät juovat mielellään isoista altaista (Jaersson ym., 1984). Altaiden äärellä esiintyy kilpailua, joten niitä tulee olla osastossa vähintään kaksi, ja ne kannattaa sijoittaa kohtiin, joissa on tilaa väistää (Anon., 2002). Väkirehun tarjontatapa, jakopisteiden lukumäärä, jakokerrat ja kerrallaan jaettavat määrät vaikuttavat eläinliikenteen sujuvuuteen ja lehmän muihin toimintoihin käytettävissä olevaan aikaan (Collis ym., 1979; Collis, 1980). Väkirehuautomaateissa takaportti on tarpeellinen, sillä automaateilla on todettu esiintyvän voimakasta kilpailua (Collis ym., 1979; Collis, 1980, Katainen, ym., 2005).

\section{Kirjallisuus}

Albright, J. L. 1993. Feeding Behavior of Dairy Cattle. Journal of Dairy Science 76:485-498.

Anon. 2002. Interdisciplinary report "Housing design for cattle Danish recommendations. Third edition 2001". 1-122.

Bewley, J., R. W. Palmer, ja D. B. Jackson-Smith 2001. A comparison of free-stall barns used by modernized Wisconsin dairies. J Dairy Sci 84:528-541.

Boe, K. E. ja G. Faerevik 2003. Grouping and social preferences in calves, heifers and cows. Appl. Anim Behav. Sci 80:175-190.

Chaplin, S. J., G. Tierney, C. Stockwell, D. N. Logue, ja M. Kelly 2000. An evaluation of mattresses and mats in two dairy units. Appl. Anim Behav. Sci 66:263-272.

Collis, K. A. 1980. Effect of An Automatic Feed Dispenser on the Behavior of Lactating Dairy-Cows. Applied Animal Ethology 6:139-147.

Collis, K. A., A. J. Quick, G. Newman, ja J. L. Albright 1979 Behavior of Lactating Dairy-Cows in An Electronic Concentrate Feeding System. Journal of Dairy Science 62:159-160.

Cook, N. B. 2003. Prevalence of lameness among dairy cattle in Wisconsin as a function of housing type and stall surface. J Am Vet Med Assoc. 223:1324-1328.

Cook, N. B. ja K. V. Nordlund 2004. Behavioral needs of the transition cow and considerations for special needs facility design. Vet Clin North Am Food Anim Pract. 20:495-520. DeVries, T.J. ja von Keyserlingk, M.A. 2006. Feed stalls affect the social and feeding behavior of lactating dairy cows. J.Dairy Sci. 89 (9):3522-3531.

Flower, F.C., de Passille, A.M., Weary, D.M., Sanderson, D.J., ja Rushen, J. 2007. Softer, higher-friction flooring improves gait of cows with and without sole ulcers. J.Dairy Sci. 90 (3):1235-1242.

Fregonesi, J. A. ja J. D. Leaver 2001. Behaviour, performance and health indicators of welfare for dairy cows housed in strawyard or cubicle systems. Livestock Prod Sci 68:205-216. Fregonesi, J. A. ja J. D. Leaver 2002. Influence of space allowance and milk yield level on behaviour, performance and health of dairy cows housed in strawyard and cubicle systems. Livestock Prod Sci 78:245-257.

Fregonesi, J. A., C. B. Tucker, D. M. Weary, F. C. Flower, ja T. Vittie 2004. Effect of rubber flooring in front of the feed bunk on the time budgets of dairy cattle. J Dairy Sci 87:12031207.

Galindo, F. ja D. M. Broom 2000. The relationships between social behaviour of dairy cows and the occurrence of lameness in three herds. Res Vet Sci 69:75-79.

Huzzey, J.M., DeVries, T.J., Valois, P. ja von Keyserlingk, M.A. 2006. Stocking density and feed barrier design affect the feeding and social behavior of dairy cattle. J.Dairy Sci. 89 (1):126-133

Jaersson, M., J. Schaar, ja H. Wiktorsson 1984. Effects of Drinking-Water Flow-Rates and Social Rank on Performance and Drinking Behavior of Tied-Up Dairy-Cows. Livestock Prod Sci 11:599-610.

Katainen, A., Norring, M., Manninen, E., Laine, J., Orava, T., Kuoppala, K. ja Saloniemi, H. 2005. Competitive behaviour of dairy cows at a concentrate self-feeder. Acta Agriculturae Scandinavica Section A-Animal Science 55 (2-3):98-105, 2005. Kjaestad, H. P. ja H. J. Myren 2001. Failure to use cubicles and concentrate dispenser by heifers after transfer from rearing accommodation to milking herd. Acta Vet Scand 42:171-180.
Kondo, S., J. Sekine, M. Okubo, ja Y. Asahida 1989. The Effect of Group-Size and Space Allowance on the Agonistic and Spacing Behavior of Cattle. Applied Animal Behaviour Science 24:127-135.

Lidfors, L. 1989. The use of getting up and lying down movements in the evaluation of cattle environments. Vet Res Commun. 13:307-324.

Livesey, C. T., C. Marsh, J. A. Metcalf, ja R. A. Laven 2002. Hock injuries in cattle kept in straw yards or cubicles with rubber mats or mattresses. Vet Rec. 150:677-679.

Manson, F. J. ja M. C. Appleby 1990. Spacing of Dairy-Cows at A Food Trough. Applied Animal Behaviour Science 26:69-81. Menke, C., S. Waiblinger, D. W. Folsch, ja P. R. Wiepkema 1999. Social behaviour and injuries of horned cows in loose housing systems. Animal Welfare 8:243-258.

Miller, K. ja D. G. M. Woodgush 1991. Some Effects of Housing on the Social-Behavior of Dairy-Cows. Animal Production 53:271-278.

Oconnell, J. M., P. S. Giller, ja W. J. Meaney 1993. Weanling Training and Cubicle Usage As Heifers. Appl. Anim Behav. Sci 37:185-195.

Olofsson, J. 1999. Competition for total mixed diets fed for ad libitum intake using one or four cows per feeding station. J Dairy Sci 82:69-79.

Phillips, C. 2002. Cattle behaviour and welfare. 2. painos:1-264. Radostits O M. 2001. Herd health: food animal production medicine. W.B.Saunders Company.

Rowlands, G. J., A. M. Russell, ja L. A. Williams 1983. Effects of Season, Herd Size, Management-System and Veterinary Practice on the Lameness Incidence in Dairy-Cattle. Vet Rec 113:441-445.

StataCorp, 2006. Stata Statistical Software: Release 9.0. Stata Corporation.

Stefanowska, J., D. Swierstra, C. R. Braam, ja M. M.

Hendriks 2001. Cow behaviour on a new grooved floor in comparison with a slatted floor, taking claw health and floor properties into account. Appl. Anim Behav. Sci 71:87-103.

Telezhenko, E. ja C. Bergsten 2005. Influence of floor type on the locomotion of dairy cows. Appl. Anim Behav. Sci 93:183197.

Tucker, C. B. ja D. M. Weary 2004. Bedding on geotextile mattresses: how much is needed to improve cow comfort? J Dairy Sci 87:2889-2895.

Tucker, C. B., D. M. Weary, ja D. Fraser 2003. Effects of three types of free-stall surfaces on preferences and stall usage by dairy cows. J Dairy Sci 86:521-529.

Vanegas J., Overton M., Berry, S.L., ja Sischo W.M. 2006. Effect of rubber flooring on claw health in lactating dairy cows housed in free-stall barns. J.Dairy Sci. 89 (11):4251-4258. Weary, D. M. ja I. Taszkun 2000. Hock lesions and free-stall design. J Dairy Sci 83:697-702.

Webster, A. J. 2001. Effects of housing and two forage diets on the development of claw horn lesions in dairy cows at first calving and in first lactation. Vet J 162:56-65.

Veissier, I., J. Capdeville, ja E. Delval 2004. Cubicle housing systems for cattle: Comfort of dairy cows depends on cubicle adjustment. J Anim Sci 82:3321-3337.

Vokey, F. J., C. L. Guard, H. N. Erb, ja D. M. Galton 2001

Effects of alley and stall surfaces on indices of claw and leg health in dairy cattle housed in a free-stall barn. J Dairy Sci $84: 2686-2699$ 